\title{
UMBARTA
}

Indonesian Journal of Anthropology

Volume 4 (1) Juli 2019 || eISSN 2528-1569 | pISSN 2528-2115 || http://jurnal.unpad.ac.id/umbara

DOI : 10.24198/umbara.v4i1.22415

\section{Pemberdayaan Masyarakat melalui Kegiatan Seni di Komunitas Celah-Celah Langit (KCCL)}

\author{
Mahesa EL Gasani \\ Komunitas Celah-Celah Langit \\ elgasanimahesa@gmail.com
}

\begin{abstract}
This research discusses community empowerment by Komunitas Celah-Celah Langit, Bandung. This research applied qualitative approach in particular auto-ethnography. Results of this research suggest that the empowerment process by Komunitas Celah-Celah Langit has been carried out through in three ways. First, by providing physical facilities such as a performance room, a library, and a discussion room to create people's awareness of education through art. Second, by providing skill-based facilities, such as theater training in order to enhance people's art creativity, especially theater. Third, by facilitating non-art self-improvement for people, such as cultural, education, and environmental awareness.
\end{abstract}

Keywords: community, community empowerment, arts, auto-ethnography, theater

\begin{abstract}
Abstrak
Penelitian ini membahas kegiatan pemberdayaan masyarakat melalui kegiatan seni yang dilakukan oleh komunitas Celah-Celah Langit, di Kota Bandung. Penelitian ini bertujuan untuk mendeskripsikan proses pemberdayaan masyarakat melalui seni. Metode yang digunakan dalam penelitian ini adalah metode auto-etnografi. Teknik pengumpulan data meliputi refleksi masa kecil peneliti sebagai anak dari penggagas Komunitas Celah-Celah Langit dan wawancara mendalam dengan penggagas komunitas. Hasil penelitian menunjukkan bahwa Komunitas Celah-Celah Langit melakukan proses pemberdayaan melalui pengembangan seni dengan tiga cara yaitu: pertama, dengan menyediakan fasilitas fisik seperti ruang pertunjukan, perpustakaan dan ruang diskusi. Penyediaan fasilitas fisik bertujuan untuk memfasilitasi masyarakat untuk berkesenian dan juga sebagai sarana edukasi dan penyadaran. Kedua, dengan menyediakan fasilitas keterampilan seni, seperti pelatihan seni teater. Implikasi dari hubungan fungsional antara aktivitas seni teater dan upaya pemberdayaan masyarakat adalah membentuk sebuah proses kreatif teater yang khas yaitu teater yang mengangkat permasalahan faktual yang terjadi di masyarakat. Ketiga, dengan memfasilitasi pengembangan diri di luar seni seperti kesadaran budaya, kesadaran pendidikan dan kesadaran lingkungan. Semua proses tersebut pada akhirnya membuahkan hasil pemberdayaan masyarakat berupa pengetahuan dan kesadaran untuk hidup berdaya.
\end{abstract}

Kata kunci : komunitas, pemberdayaan masyarakat, seni, auto-etnografi, teater 


\section{Pendahuluan}

Seni tak lepas dari kehidupan sehari-hari manusia. Setiap aspek kehidupan manusia mengandung unsur seni baik disadari maupun tidak. Berbagai kegiatan mengandung unsur seni, bahkan saat individu yang sedang berdiam diri pun dapat dikatakan mengandung unsur seni jika dilihat dari sudut pandang seni. Seni adalah elemen yang sangat cair di kehidupan manusia. Seni dapat menjadi produk promosi perdamaian di daerah konflik. Seni juga dapat digunakan sebagai tujuan politik, sosial, ekonomi, bahkan untuk tujuan pemberdayaan masyarakat.

Penelitian ini memaparkan sebuah kegiatan pemberdayaan masyarakat di Kelurahan Ledeng, Kecamatan Cidadap, Kota Bandung yang dilakukan melalui kesenian. Kegiatan ini dilakukan oleh komunitas kesenian yang bernama Celah-Celah Langit (CCL). Kelurahan Ledeng adalah wilayah yang saat ini digunakan sebagai terminal angkutan umum. Kawasan terminal merupakan kawasan publik yang rawan dengan konflik dan kekerasan. Namun, secara historis, masyarakat di Kelurahan Ledeng memiliki potensi seni dan sangat suka berkesenian. Warga Kelurahan Ledeng sebagian besar adalah seniman, pemain wayang, pesilat, pesinden, pemain Bring-brung dan sebagainya. Mereka biasanya melakukan aktivas kesenian bersama. Sejak 1972, mereka tidak lagi aktif berkesenian karena lokasi tempat mereka beraktivitas dibangun oleh pemerintah menjadi terminal angkutan umum. Selain hilangnya lokasi berkesenian, kemunduran aktivitas seni warga Ledeng juga disebabkan oleh faktor lain, salah satunya mata pencaharian. Seni adalah pekerjaan sambilan para seniman di Kelurahan Ledeng. Ma sing-masing dari mereka memiliki pekerjaan utama yang menopang kehidupan ekonomi rumah tangga mereka. Misal, seorang vokalis band memiliki pekerjaan utama sebagai kuli bangunan, aktor teater memiliki pekerjaan utama sebagai pengamen jalanan, dan pemain kendang yang memiliki pekerjaan utama se- bagai penjual bakso goreng. Kesibukan dalam mencari nafkah itu membuat para seniman terkendala melakukan aktivitas seni. Namun, masih ada sebagian kecil warga Ledeng yang tetap setia berkesenian bahkan mendirikan komunitas seni; salah satunya adalah Iman Soleh. Ia adalah seniman asli warga Ledeng yang menggagas pendirian sebuah komunitas seni bernama Komunitas Celah-Celah Langit.

Selain memiliki visi mengembangkan seni teater, komunitas ini juga memiliki visi memberdayakan masyarakat sekitar. Komunitas ini memnfasilitasi dan menyediakan sarana berkreativitas untuk menambah kapasitas pengetahuan dan daya kreatif bagi setiap anggota komunitas dan masyarakat yang terlibat dalam kegiatan di komunitas ini. Tujuannya agar para warga sekitar mampu berdaya secara sosial dan ekonomi. Fokus pemberdayaan oleh komunitas ini adalah edukasi dan pembelajaran etika dan estetika. Implementasi visi dan misi dari komunitas ini dilakukan melalui dua hal, yaitu 1) proses kreatif produksi teater dan 2) kegiatan di luar proses kreatif. Kegiatan di luar proses kreatif meliputi pemberdayaan individu dan penyediaan fasilitas berkesenian untuk masyarakat.

Penelitian mengenai pemberdayaan ma syarakat melalui seni pernah dilakukan oleh Zaini (2007). Ia meneliti Sanggar Alang-Alang Surabaya yang melakukan kegiatan pemberdayaan anak jalanan melalui kegiatan seni. Penelitian tersebut berangkat dari asumsi bahwa persoalan penanganan anak jalanan dan pengembangannya tidak cukup dilakukan melalui dengan pendekatan sosial dan eknomi, tapi juga perlu memperhatikan persoalan budaya mereka. Budaya anak jalanan berupa pola pikir, sikap mental, dan nilai-nilai yang dianut perlu diubah dalam rangka memberdayakan mereka. Cara mengubah hal tersebut adalah melalui pembelajaran seni. Pembelajaran seni di Sanggar Alang-Alang Surabaya menjadi media untuk mengubah budaya anak jalanan. Anak-anak diajari menerapkan nilainilai, estetika, etika sosial, budaya, dan agama 
melalui seni. Penelitian tersebut menyimpulkan bahwa seni dapat menjadi sarana memberdayakan anak jalanan.

Penelitian mengenai Komunitas Celah-Celah Langit pada dasarnya pernah dilakukan, antara lain oleh Djojopoespito (2006) dan Setiawan (2009). Namun, kedua penelitian tersebut tidak secara khusus menyoroti kegiatan pemberdayaan masyarakat yang dilakukan Komunitas Celah-Celah Langit. Setiawan (2009) menyoroti kemunculan dan perkembangan Komunitas Celah-Celah Langit sebagai sebuah komunitas seni; dan Djojopoespito (2006) menyoroti Komunitas Celah-Celah langit sebagai bagian dari Centre-Cultures Ledeng yang berperan penting dalam upaya meningkatkan citra pariwisata Kota Bandung. Penelitian mengenai kegiatan yang dilakukan oleh Komunitas Celah-Celah Langit dalam konteks pemberdayaan masyarakat belum pernah dilakukan. Penelitian ini mengisi kekosongan kajian pemberdayaan masyarakat yang dilakukan oleh Komunitas Celah-Celah Langit di Kota Bandung.

\section{Kajian Pustaka}

\section{Pemberdayaan Masyarakat}

Pemberdayaan masyarakat adalah salah satu metode pekerjaan sosial yang bertujuan memperbaiki kualitas hidup masyarakat melalui pendayagunaan sumber-sumber yang ada pada mereka serta menekankan pada partisipasi sosial. Fokus utama pemberdayaan masyarakat adalah upaya menolong anggota masyarakat yang memiliki kesamaan minat untuk bekerjasama, mengidentifikasi kebutuhan bersama dan kemudian melakukan kegiatan bersama untuk memenuhi kebutuhan tersebut (Suharto, 2009). Tujuan akhir dari sebuah pemberdayaan masyarakat adalah terealisasinya masyarakat yang berdaya $(\mathrm{em}$ powered society). Masyarakat berdaya adalah masyarakat yang mampu mandiri dalam berpikir, bersikap, dan mengambil tindakan serta sudah mampu berorientasi jangka panjang, makro dan substansial (Zubaedi, 2013).
Pemberdayaan masyarakat juga merujuk pada sebuah upaya penyadaran dan peningkatan daya pada diri seseorang atau kelompok untuk memahami dan mengontrol dimensi-dimensi kekuatan yang dimiliki (religi, fisik, psikis, sosial, ekonomi, politiik dan budaya) dengan tujuan meningkatkan kedudukan mereka di masyarakat (Kindervatter, 1979). Pemberdayaan masyarakat pada hakikatnya merupakan bentuk perubahan. Proses pemberdayaan tidak akan berjalan apabila perubahan budaya secara mendasar di masyarakat tidak dilakukan. Perubahan budaya sangat penting karena untuk mendukung upaya perubahan sikap dan praktik menuju situasi yang lebih efektif (Sumaryadi, 2005).

Pemberdayaan masyarakat memiliki lima prinsip dasar, yaitu, 1) Memiliki orientasi yang berbeda dengan bisnis, artinya keuntungan yang diperoleh melalui kegiatan pemberdayaan akan didistribusikan kembali dalam bentuk program atau kegiatan pembangunan lainnya bagi masyarakat secara luas; 2) Pemberdayaan masyarakat selalu melibatkan partisipasi masyarakat baik dalam perencanaan maupun pelaksanaan yang dilakukan; 3) Kegiatan pelatihan merupakan unsur yang tidak dapat dipisahkan dari usaha pembangunan fisik; 4) Memaksimalkan sumber daya dalam pengimplementasiannya; 5) Kegiatan pemberdayaan masyarakat harus dapat berfungsi sebagai penghubung antara kepentingan pemerintah yang bersifat makro dengan kepentingan masyarakat yang bersifat mikro (Rubin dalam Sumaryadi, 2005).

Selain kelima prinsip tersebut, pemberdayaan masyarakat juga harus memperhatikan tiga prinsip lainnya, yaitu: 1) Kontekstualisme, yakni kegiatan pemberdayaan harus difokuskan pada pemahaman individu atau kelompok sendiri terhadap kesejahteraan dirinya; 2) Empowerment, yaitu proses di mana pemberdaya akan mendukung individu atau kelompok untuk mengidentifikasi kemungkinan kebutuhannya. Hal ini bertujuan agar individu atau kelompok membuat keputusan tindakan yang 
perlu dilakukan; dan 3) Collectivity, yaitu fokus pada pengurangan perasaan terisolasi dan membuat hubungan dengan individu/ kelompok yang lain (Payne, 1991).

Proses pemberdayaan masyarakat dapat dimaknai sebagai runtutan perubahan yang bertujuan untuk membuat masyarakat menjadi lebih berdaya. Proses pemberdayaan masyarakat terdiri atas empat tahapan, yaitu: 1) Awakening atau penyadaran, pada tahap ini masyarakat disadarkan akan kemampuan, sikap dan keterampilan yang dimiliki serta rencana dan harapan akan kondisi mereka yang lebih baik dan efektif; 2) Understanding atau pemahaman, lebih jauh dari tahapan penyadaran, masyarakat diberikan pemahaman dan persepsi baru mengenai diri mereka sendiri, aspirasi mereka dan keadaan umum lainnya. Proses pemahaman ini meliputi proses belajar untuk secara utuh menghargai pemberdayaan dan tentang apa yang dituntut dari mereka oleh komunitas; 3) Harnessing atau memanfaatkan, setelah masyarakat sadar dan mengerti mengenai pemberdayaan, mereka memutuskan untuk menggunakannya bagi kepentingan komunitasnya; 4) Using atau menggunakan keterampilan dan kemampuan pemberdayaan sebagai bagian dari kehidupan sehari-hari.

Pembangunan dalam paradigma pemberdayaan masyarakat bersifat people-centered (berpusat pada manusia), participatory (partisipatoris), empowering (memberdayakan), dan sustainable (berkelanjutan) (Chambers, 1995). Upaya yang dilakukan di dalam memberdayakan masyarakat terdiri atas empat dimensi, yaitu: 1) Menciptakan suasana atau iklim yang memungkinkan masyarakat berkembang (enambling),(2) Memperkuat potensi atau daya yang dimiliki oleh masyarakat (empowering). Upaya penguatan ini meliputi langkah-langkah nyata, dan menyangkut penyediaan berbagai masukan (input), serta pembukaan akses ke dalam berbagai peluang (opportunities) yang akan membuat masyarakat makin berdaya, 3) Memberdayakan mengandung pula arti melindungi (Kartasasmita, 1996).

Pemberdayaan masyarakat harus mengikuti beberapa pendekatan yaitu: (a) Merupakan upaya yang terarah (targeted) atau pemihakan; (b) Langsung mengikutsertakan atau dilaksanakan oleh masyarakat yang menjadi sasaran; (c) Menggunakan pendekatan kelompok, karena apabila menggunakan pendekatan individu masyarakat yang miskin sulit dapat memecahkan permasalahan yang dihadapinya (Kartasasmita, 1996).

Konsep pemberdayaan dalam paradigma pembangunan masyarakat pada sebuah komunitas dapat dianggap sebagai konsep yang relatif lebih baik dan membawa manfaat yang lebih besar. Namun, dalam implementasinya masyarakat tidak selalu ikut serta dan berpartisipasi penuh dalam program tersebut karena berbagai faktor. Faktor-faktor yang memengaruhi pemberdayaan masyarakat, yaitu: 1) Kesediaan suatu komunitas untuk menerima pemberdayaan bergantung pada situasi yang dihadapinya; 2) Pemikiran bahwa pemberdayaan tidak untuk semua orang, dan adanya persepsi dari pemegang kekuasaan dalam komunitas tersebut bahwa pemberdayaan dapat mengorbankan diri mereka sendiri; 3) Budaya ketergantungan, di mana masyarakat sudah terbiasa berada dalam hirarki, birokrasi dan kontrol manajemen yang tegas sehingga cenderung bergantung dan tidak kritis; 4) Dorongan dari para pemimpin setiap komunitas untuk tidak melepaskan kekuasaannya, karena inti dari pemberdayaan adalah berupa pelepasan sebagian kewenangan untuk diserahkan kepada masyarakat sendiri; 5) Adanya batas pemberdayaan, terutama terkait dengan siklus pemberdayaan yang membutuhkan waktu relatif lama di mana pada sisi yang lain kemampuan dan motivasi setiap orang berbeda-beda; 6) Adanya kepercayaan dari para pemimpin komunitas untuk mengembangkan pemberdayaan dan mengubah persepsi mereka tentang anggota komunitasnya; 7) Pemberdayaan tidak kondusif bagi perubahan yang cepat; 
8) Pemberdayaan membutuhkan dukungan sumber daya (resource) yang besar, baik dari segi pembiayaan maupun waktu (Sumaryadi, 2005). Hasil dari sebuah upaya pemberdayaan akan sangat tergantung dari kondisi masyarakat dan peran serta semua stakeholder yang terlibat dalam program pemberdayaan tersebut.

\section{Seni dan Teater}

Seni merupakan segala ekspresi hasrat manusia akan keindahan. Seni secara umum terbagi menjadi dua kelompok, yaitu : (a) seni rupa, atau kesenian yang dinikmati oleh manusia dengan mata, dan (b) seni suara, atau kesenian yang dinikmati oleh manusia dengan telinga. Salah satu bentuk kesenian yang meliputi keseluruhan antara seni rupa dan seni suara adalah teater, karena di dalamnya mengandung unsur-unsur dari seni lukis, seni rias, seni musik, seni sastra dan seni tari yang semua diintegrasikan menjadi satu kebulatan (Koentjaraningrat, 2015).

Teater berasal dari bahasa Yunani: theatron yang berarti panggung tempat penonton, sebuah bangunan yang dibangun untuk menjadi tempat berlangsungnya sebuah peristiwa tontonan, yang kemudian dinamakan teater. Dalam perjalanan selanjutnya, teater lebih merujuk pada pertunjukan seni drama atau kelompok drama. Drama juga berasal dari bahasa Yunani, yang berarti dialog dalam bentuk puisi atau prosa dengan keterangan laku. Padan kata drama dalam bahasa Indonesia adalah sandiwara (Sayoga: 1985). Teater terdiri atas beberapa unsur, di antaranya unsur internal seperti naskah atau skenario, pemain, sutradara, pentas, properti dan penataan, serta unsur eksternal yang terdiri atas staf produksi, sutradara atau director, stage manager, desainer dan crew. Teater adalah sebuah seni kolektif yang merupakan gabungan seni musik, seni laku, seni suara, seni tari, seni sastra dan bahkan multimedia, yang memiliki potensi untuk memberikan pengalaman batin baik kepada para pendukungnya maupun penonton.
Fungsi teater antara lain: 1) Fungsi hiburan; 2) Fungsi ritual; 3) Fungsi ekspresi (kreatif); 4) Fungsi ekonomi, 5) Fungsi kritik sosial. Teater berfungsi sebagai hiburan karena teater dapat memberikan hiburan bagi para penontonnya. Teater berfungsi ritual karena upacara ritual, dalam konteks kehidupan adat dan agama meruapakan proses teateral. Di dalamnya terdapat tahapan-tahapan dan elemen-elemen teateral berupa ruang dan waktu, gerakan, suara dan nyanyian, rasa dan jiwa, dan panggung/tempat upacara; 3) Fungsi ekspresi (kreatif). Teater adalah narasi dan sekaligus ekspresi. Sebagai narasi, teater memuat cerita, informasi, mencatat peristiwa dan merekam berbagai hal, sehingga tak kurang sebagai saksi zaman. Sebagai ekspresi, teater mencatat opini, jalan pikiran serta kehendak dari orangorang pada suatu masa tertentu. Teater juga dapat menjadi dokumentasi jati diri manusia pada suatu masa tertentu; 4) Fungsi Ekonomi. Perbedaan terpenting dalam proses teater Barat dan Timur adalah bahwa di Timur, umumnya di negara-negara berkembang, teater adalah process oriented. Di Barat, produksi teater adalah product oriented; 5) Fungsi kritik dan komentar sosial. Teater adalah sebuah lembaga untuk bersuara dan berbicara kepada masyarakat. Kritik menjadi sangat dekat dengan teater, baik yang halus, yang rahasia, maupun yang menohok dan frontal. Teater adalah alat berbicara kepada publik dan sebaliknya berbicara kepada kekuasaan. Di dalam teater tradisi, fungsi teater sebagai media kritik sosial merupakan sesuatu yang dianggap wajar. Biasanya kritik akan diterima dengan baik apabila kritik itu disampaikan dengan ramah, santun, terselubung sehingga sangat tepat bila dilakukan melalui humor.

\section{Metode}

Penelitian ini menggunakan metode auto-etnografi yang didefinisikan oleh Buzard (2003) sebagai suatu studi, representasi atau pengetahuan suatu budaya oleh satu atau lebih anggota budaya tersebut. Buzard (2003) dan Jackson (2008) memberikan pandangan bahwa au- 
to-etnografi sebagai suatu pendekatan alternatif penelitian dan penulisan yang mencari cara untuk mendeskripsikan dan secara sistematis menganalisis (graphy) pengalaman personal (auto) untuk memahami pengalaman kultural (ethno). Auto-etnografi memandang tempat sebagai suatu yang tidak fix, namun tempat penelitian (atau budaya) sebagai suatu yang portable (Buzard, 2003). Oleh karena itu, tulisan auto-etnografi ini merupakan bentuk narasi diri yang menempatkan diri peneliti dalam konteks sosial tertentu, yang berangkat dari refleksi diri (self).

Auto-etnografi mengakui konsep "traveling culture". Auto-etnografi memandang konsep "insider-outsider" bukan sebagai konsep yang terpisah, namun sebagai konsep "singular universal" atau "etnography biography" atau "subjective in-between" (Buzard, 2003; M. D. Jackson, 2008). Oleh karena itu, sebagai suatu tulisan auto-etnografi, posisi peneliti juga menempati posisi sebagai subjek (inpotential), dan juga bagian dari komunitas sosial tertentu (in presentia) (Buzard, 2003).

Teknik yang dilakukan dalam penelitian ini adalah refleksi pengalaman-pengalaman peneliti sebagai anak kandung Iman Soleh, penggagas Komunitas CCL. Refleksi pengalaman peneliti sejak masih remaja, saat peneliti mulai terlibat dalam proses kreatif teater hingga saat penelitian ini dilakukan menjadi bahan analisis dalam penelitian ini. Teknik pengumpulan data juga dilakukan dengan wawancara mendalam para informan, yaitu penggagas Komunitas Celah-Celah Langit, para seniman yang berkegiatan di komunitas tersebut, dan masyarakat yang terlibat dalam kegatan di komunitas ini. Studi dokumen, dan arsip foto yang dimiliki oleh Komunitas Celah-Celah Langit juga dilakukan untuk melengkapi data.

\section{Hasil dan Pembahasan}

\section{Riwayat Komunitas Celah-celah Langit}

Komunitas Celah-celah Langit terletak di jalan Gang Bapa Eni 169/8a Ledeng Ban- dung, tepatnya di belakang terminal Ledeng. Pada 1980-1985, Tisna Sanjaya, seorang seniman asli Ledeng, merintis aktivitas kesenian bersama rekan-rekannya di lahan berukuran $12 \times 7$ meter yang awalnya adalah kebun dan kandang ayam. Kegiatan seni yang dilakukan adalah seni rupa. Kelompok kesenian ini dikenal dengan nama Komunitas "Gang Bapa Eni" karena kegiatan kesenian tersebut berlokasi di Gang Bapa Eni. Pada saat itu aktivitas kesenian yang mereka lakukan belum terorganisir dengan baik.

Pada 1986, Iman Soleh (kakak dari Tisna Sanjaya) bergabung ke dalam Komunitas Seni Gang Bapa Eni. Bergabungnya Iman Soleh membawa warna baru untuk Komunitas Gang Bapa Eni, karena ia adalah seorang seniman teater. Kegiatan kesenian Komunitas Gang Bapa Eni pun meluas cakupannya. Pada tahun itu pula Iman Soleh mengusulkan nama baru untuk Komunitas Gang Bapa Eni yaitu "Komunitas Serikat Kesenian Bandung". Nama tersebut terinspirasi dari nama Serikat Dagang Islam dan Serikat Islam. Pada 1989 mayoritas anggota komunitas telah menyelesaikan studinya, sehingga banyak dari mereka aktif berkegiatan di luar komunitas. Sejak saat itu Iman Soleh berperan meneruskan kegiatan komunitas. Secara spontan fokus kegiatan komunitas pun sedikit berubah dari seni rupa menjadi teater. Warna teater makin kuat saat rekan-rekan Iman Soleh yang notabene adalah para seniman teater bergabung; di antaranya Tony Broer, Didin Sirojudin, Tatang Abdulah, Kristiawan, Kodrat, Gumilar, Setiawan, Asep Budiman dan Gaus Firdaus.

Sekitar 1994- 1995 terjadi ketegangan politik di Kota Bandung. Pada masa itu pemerintah mencurigai banyak organisasi atau komunitas melawan pemerintah Orde Baru, atau dianggap sebagai organisasi kekirian. Komunitas tersebut biasanya dikenai cap sebagai "komunitas tanpa bentuk". Jika telah mendapat cap tersebut, organisasi atau komunitas tersebut dalam bahaya sebab pemerintah mengancam membubarkan organisasi yang demikian. Ko- 
munitas Serikat Kesenian Bandung menjadi salah satu perkumpulan yang dicurigai oleh pemerintah dan terkena label "komunitas tanpa bentuk". Pemberian label itu bermula saat Komunitas Serikat Kesenian Bandung mementaskan sebuah pertunjukan berjudul "Ruang Tunggu Bapak-Bapak". Kisah Ruang Tunggu Bapak-Bapak menceritakan mengenai situasi politik pada masa orde baru. Naskah tersebut dibuat oleh Gingginanjar, dan isi dari pertunjukan teater tersebut memang berupa kritik pada pemerintah saat itu yang cenderung represif. "Bapak-bapak" merupakan simbol dari orang-orang yang diam dan tidak berdaya terhadap situasi pada zaman-nya. Ruang Tunggu Bapak-Bapak dipentaskan di Bandung dan TIM Jakarta bertepatan dengan situasi politik di Jakarta yang saat itu tidak menentu. Saat pertunjukan berlangsung, tempat pertunjukkan dijaga ketat oleh aparat keamanan. Pertunjukan ini juga dianggap salah satu kegiatan gerakan ke kiri-kirian. Padahal, sebenarnya pertunjukan itu bermaksud mengkritisi para politisi dan juga pemerintah yang cenderung tidak memiliki keberanian pada kekuatan besar dari rezim Orde Baru.

Dampak dari pementasan teater "Ruang Tunggu Bapak-Bapak" adalah penangkapan beberapa anggota Komunitas Serikat Kesenian Bandung pada tahun 1996. Alasan yang dikemukakan oleh aparat adalah karena komunitas ini sering mementaskan naskah-naskah Eropa Timur. Padahal menurut Iman Soleh, isi naskah-naskah tersebut tidak ada kaitannya dengan angenda kekirian atau komunisme.

Iman Soleh dan beberapa anggota Komunitas Serikat Kesenian Bandung dilepaskan kembali karena tidak terbukti bersalah. Namun, mereka sempat mengalami intimidasi dan kekerasan fisik oleh aparat yang menangkapnya. Kejadian tersebut, membuat aktivitas Komunitas Serikat Kesenian Bandung terhenti. Para anggota tidak berani lagi melakukan aktivitas kesenian karena khawatir ditangkap. Jatuhnya Rezim Orde Baru 21 Mei 1998 men- jadi momentum bagi kebebasan berpendapat dan berekspresi, termasuk bagi para seniman. Iman Soleh berinisiatif untuk mengadakan pertunjukan teater di halaman rumah pada 22 Mei 1998 sebagai bentuk perayaan jatuhnya rezim. Pertunjukan tersebut menjadi awal munculnya kembali gairah berkesenian Iman Soleh dan rekan-rekannya. Pada saat itu mereka memiliki gagasan membentuk komunitas baru bernama Komunitas Centre Culture of Ledeng. Nama ini dipilih karena komunitas ini mereka harapkan menjadi pusat kebudayaan di Ledeng; dan menarik banyak aktivis seni dari masyarakat Ledeng maupun luar Ledeng.

Pada akhir 1998, atas usul Sawung Jabo, salah seorang musisi ternama dari grup Kantata, nama Centre Culture of Ledeng diubah menjadi Komunitas Celah-Celah Langit. Menurutnya, Celah-Celah Langit nama yang sederhana, tidak terlalu mistis, dan tidak perlu diupacara-adatkan. Secara resmi, Komunitas Celah-Celah Langit berdiri pada 22 Mei 1998. Visi-misi Komunitas Celah-Celah Langit mengutamakan pada nilai di mana warga Ledeng dan anggota Komunitas Celah-Celah Langit memiliki hak yang sama dalam berkesenian. Kesenian yang diupayakan adalah kesenian dengan kualitas yang bagus, kesenian yang kritis, dan juga kesenian yang beragam, serta berdampak memberdayakan Bagi Komunitas Celah-Celah Langit, kesenian adalah pintu masuk pemberdayaan.

\section{Aktivitas Seni di Komunitas Celah-Celah Langit}

Sejak resmi berdiri pada 1998, selain kembali aktif berkesenian, arah kegiatan komunitas lebih terorganisir. Program Komunitas Celah-Celah Langit memiliki beberapa tipe, yaitu yang diperuntukkan untuk internal dan eksternal komunitas. Program internal komunitas terfokus kepada teater, di dalamnya terdiri atas unsur musik sebagai penata musik, unsur seni rupa sebagai penata artistik, unsur tari sebagai penata gerak, unsur sastra tulis sebagai naskah dan unsur sastra lisan sebagai pem- 
eranan. Kegiatan untuk eksternal komunitas berupa memfasilitasi kelompok kesenian lain untuk melangsungkan pertunjukan di Komunitas Celah-Celah Langit. Kegiatan eksternal menghasilkan interaksi seni dengan berbagai seniman. Sejak 1998, komunitas kesenian dari Aceh, Papua, Australia, Jerman, Yunani, Serbia, Perancis dan Cina melakukan pementasan di Komunitas Celah-Celah Langit. Selain merangkul seniman dan komunitas lainnya, Komunitas Celah-Celah Langit selalu berupaya untuk mendorong partisipasi masyarakat sekitar dalam setiap kegiatan yang digelar.

\section{Proses Pemberdayaan Masyarakat}

Pengembangan seni oleh Komunitas CCL dilakukan melalui 3 cara, yaitu: 1) Penyediaan fasilitas fisik berupa ruang pertunjukan, perpustakaan, ruang diskusi dan saung. 2) Penyediaan fasilitas keterampilan seni yaitu seni teater. 3) Penyediaan kegiatan pengembangan diri di luar seni, misal kesadaran terhadap budaya, lingkungan dan pendidikan.

\section{Penyediaan fasilitas Fisik}

Fasilitas fisik utama yang disediakan KCCL bagi kegiatan pemberdayaan adalah sebuah panggung pertunjukan. Pada 1980 hingga sebelum 2005 hanya berupa lapangan tanah. Jika ada pementasan, penonton duduk di lantai tanah beralaskan karpet. Pada 2005, Iman Soleh memperkeras lapangan dengan semen dan membuat tempat duduk bagi penonton serupa amfiteater di sekeliling lapangan. Pada tahun 2013, Komunitas CCL mendapat sumbangan dari donatur untuk merenovasi area pertunjukan menjadi lebih baik lagi. Area pertunjukan yang semula hanya menggunakan semen, direnovasi menggunakan batu kali dan batu candi menjadi lebih indah.

Panggung pertunjukan ini dapat digunakan untuk kegiatan latihan atau pagelaran oleh masyarakat umum. Selain untuk berkesenian, panggung juga boleh digunakan oleh warga Ledeng untuk menggelar hajatan khitanan atau pernikahan secara gratis.
Selain panggung, fasilitas fisik lainnya yang tersedia adalah perpustakaan. Perpustakaan ini berdiri pada 2013 bertepatan dengan renovasi ruang berkesenian di KCCL. Perpustakaan dibangun sebagai ruang edukasi bagi masyarakat yang datang; baik anak-anak, remaja, hingga dewasa terutama mahasiswa yang ingin memenuhi kebutuhan literasinya. Koleksi buku yang terdapat di perpustakaan CCL beragam, antara lain buku-buku sastra, sejarah, seni budaya, sosial, ilmu pengetahuan alam hingga buku komik untuk anak-anak. Koleksi tersebut diperoleh dari sumbangan warga, perpustakaan nasional juga buku pri badi milik anggota komunitas.

Bagi para mahasiswa, perpustakaan di Komunitas CCL juga dapat dimanfaatkan sebagai ruang mengerjakan tugas kuliah dan berdiskusi. Bagi anak-anak, perpustakaan Komunitas CCL digunakan untuk membaca buku komik bergambar dan saling bertukar informasi mengenai buku yang mereka baca. Bagi para seniman, perpustakaan tersebut dimaanfaatkan sebagai tempat mempelajari naskah-naskah teater, atau mencari referensi baru untuk garapan teater. Iman Soleh menyimpan semua naskah teater yang dimilikinya agar para anggotanya mempunyai banyak referensi terkait seni teater yang mereka garap.

Selain perpustakaan yang dapat dimanfaatkan untuk diskusi, tersedia pula ruang khusus untuk diskusi. Ruang diskusi ada dua, satu ruang terletak ruang depan yang menjadi kantor Iman Soleh, dan satu ruang lagi terletak ruang pendopo yang dapat digunakan oleh masyarakat umum.

Ruang depan dibangun pada tahun 2005. Ruang tersebut digunakan untuk menyambut tamu-tamu kehormatan yang datang ke Komunitas Celah-Celah Langit misal menteri pendidikan, walikota, dan sebagainya. Ruangan tersebut dibuat tertutup, dan bebas dari asap rokok. Ruang pendopo juga dapat digunakan menjadi ruang diskusi yang santai dan terbuka. Siapa saja dapat berdiskusi, bercengkrama, bermain gitar, ataupun memba- 
ca puisi di ruang pendopo ini. Fasilitas dapur seperti kompor gas, dispenser, kopi dan mie instan juga disediakan bagi semua orang yang berada di KCCL. Setiap orang yang menggunakan fasilitas wajib membereskannya kembali.

\section{Penyediaan Fasilitas Keterampilan Seni}

Kegiatan kesenian di CCL berbeda dan mempunyai upaya pemberdayaan jika dibandingkan dengan kelompok seni lain. Misal, di kelompok kesenian lain, semua proses latihan tergantung kepada guru. Semua pemahaman anggota kelompok seni mengenai sebuah ke senian terbatas pada hal-hal yang diajarkan oleh guru pada murid, tidak lebih. Di CCL, para pekerja seni dipaksa untuk mengeksplo rasi lebih dari yang diajarkan oleh guru, mencari jenis, bentuk, dan variasi yang berbeda dari sebuah seni, yang tidak biasa didengar apalagi dikaitkan dengan teater. Sering kali Iman Soleh mendorong para seniman muda untuk banyak menonton pertunjukan-pertunjukan musik, mempelajari bunyi, mempelajari bentuk, hingga akhirnya saya memahami apa bentuk musik. Namun, terkadang ia juga menyarankan mereka mempelajari hal yang menurut para seniman muda sangat simpel seperti contoh suara langkah, atau suasana sehari-hari yang sering kali tidak disadari. Saat mempersiapkan ilustrasi musik "Tanah Ode Kampung Kami", para seniman muda dianjurkan oleh Iman Soleh untuk mempelajari suara langkah tentara, nada-nada pengucapan doa, suara konflik yang saya rasa jarang saya sadari proses belajar tersebut, mendorong para seniman muda menambah daya kreativitas dalam mengenal dan menciptakan bentuk baru di dunia musik maupun teater. Iman Soleh seringkali menjelaskan perbedaan proses krea tif teater konvensional dan yang ia lakukan di Komunitas Celah-Celah Langit. Menurutnya, proses produksi teater konvensional melalui beberapa langkah umum yaitu langkah-langkah yang bersumber pada tiga hal besar yaitu naskah, sutradara, dan pemain. Pada umunya teater konvensional menggu- nakan metode yang baku, tahapan tersebut di antaranya: menentukan gagasan yang bersumber dari naskah yang sudah ditulis oleh para dramawan atau penulis naskah sebelumnya; memilih naskah; mempelajari peran; menentukan pemain berdasarkan casting; mendesain artistik atau panggung; mempersiapkan pro perti panggung atau kebutuhan panggung; dan pertunjukan dan evaluasi.

Di Komunitas Celah-Celah Langit metode khas yang dilakukan dalam proses kreatif meliputi beberapa tahap proses. Pertama, memilih dan mengumpulkan para pemain: pemain yang dilibatkan oleh CCL bukan hanya orang yang sudah professional di bidang teater, melainkan juga masyarakat sekitar yang pada umumya awam terhadap seni teater. Hal ini menegaskan bahwa teater yang digiatkan oleh CCL merupakan teater kerakyatan yang berupaya melibatkan partisipasi warga masyarakat, dan juga menajdi saranan mengungkapkan isi hati masyarakat terkait permasalahan yang dialami oleh masyarakat. Kedua, menentukan ide atau gagasan: pada umumnya, ide atau gagasan yang diangkat untuk sebuah produksi teater Komunitas CCL tidak bersumber dari naskah yang sudah ada. Ide didasarkan pada isu aktual dan kontekstual. Isu aktual adalah isu yang hangat dan sedang terjadi di masyarakat, isu kontekstual adalah isu yang sesuai dengan keadaan. Contoh gagasan yang dilahirkan oleh para pemain teater di Komunitas Celah-Celah Langit adalah "Bedol Desa 1" dan "Bedol Desa 2" yang mengangkat isu mengenai pemindahan secara paksa sebuah desa atas nama pembangunan pada 2003. Ketiga, pematangan ide atau gagasan: pematangan ide dilakukan dengan melakukan riset sosial setelah para pemain bersepakat mengenai gagasan yang akan diangkat dan diproses untuk dijadikan sebuah tema pementasan. Ide dan gagasan tersebut diolah bersama para pemain, sehingga para pemain memahami apa yang mereka mainkan. Proses pematangan menambah pengetahuan para pemain dan sutradara mengenai isu yang diangkat. Selain itu, setiap pemain pun men- 
jadi bertambah daya kritis dan kepekaannya terhadap situasi sosial di sekeliling. Keempat, membuat naskah: di Komunitas CCL, naskah ditulis secara kolektif. Iman Soleh biasanya meminta pemain untuk menuliskan dialognya sendiri dengan tema yang sudah disepakati. Setiap pemain didorong untuk mengutarakan pendapat mengenai ide yang sedang dibahas sehingga menjadi lebih kritis terhadap permasalahan yang sedang diangkat dan berkontribusi pada kualitas pertunjukkan. Kelima, latihan eksplorasi: latihan eksplorasi bertujuan membentuk para pemain. Saat melakukan eksplo rasi, pemain didorong untuk mencari bunyi-bunyi yang dapat mengantarkan pertunjukan dan membawa suasana pertunjukan terasa hidup. Keenam, desain artistik dan panggung: pada tahap ini, para pemain mempersiapkan properti dan pementasan yang berbeda dengan teater konvensional. Pada pertunjukan Teater Tanah Ode Kampung Kami yang menggambarkan suasana sawah dan ilalang, para pemain berupaya menemukan properti yang sesuai. Pilihan jatuh pada bambu karena bambu menggambarkan identitas desa; memiliki sifat sederhana namun kuat dan guyub. Setiap pemain tidak hanya dituntut bisa bermain tetapi juga harus dapat mengerjakan bagian artistk. Iman Soleh menegaskan bahwa belajar teater tidak hanya terfokus pada musik saja tetapi harus pula mempelajari semua unsur teater. Ketujuh, memilih tempat pertunjukan: tempat pementasan dipilih atas pertimbangan kesesuaian dengan tema pertunjukan atau tempat yang memiliki persoalan dengan kasus-kasus yang diangkat dalam pertunjukan. Biasanya pertunjukan teater CCL yang digelar di tempat yang relevan dengan isu yang diangkat. Misal pementasan naskah teater berjudul "Air" pada 2006 diselenggarakan di Lahore Pakistan, karena saat itu kelangkaan air tengah terjadi di Negara tersebut. Selain "Air" naskah "Tanah" pun dipentaskan di tempat yang relevan yaitu di Jatiwangi, Lembang, Purwakarta, Jakarta Art Summit, STSI dan Mayang Sunda. Pemilihan tempat pementasan yang relevan menurut Iman Soleh dimaksudkan untuk mengedukasi penonton tentang persoalan sosial yang sesungguhnya dekat di sekitar mereka. Kedelapan, pertunjukan: pertunjukan di Komunitas CCL selalu mendapatkan sambutan yang baik. Hal itu tampak dari jumlah penonton yang selalu banyak di setiap pertunjukan. Umumnya para penonton terdiri dari berbagai kalangan seperti politikus, akademisi, aktivis, masyarakat umum dan mahasiswa. Pada setiap acara yang digelar oleh Komunitas Celah-Celah Langit selalu mempunyai keunikan tersendiri. Misal pada acara Agustusan memperingati hari kemerdekaan Indonesia. Setiap pertunjukan yang ditampilkan di CCL tidak hanya berbicara mengenai seni, tetapi ada makna di balik itu semua, yaitu pesan mengenai kritik sosial. Anak-anak Ledeng yang menjadi panitia, sekaligus pengisi acara pun sangat memahami makna itu dan mereka sangat antusias dengan ide tersebut. Kesembilan, tahap evaluasi. Tahap ini dibagi dua yaitu evaluasi teknis dan evaluasi dampak dari proses garapan yang dilakukan. Di dalam tahap evaluasi teknis, Iman Soleh sering memberi kritik me ngenai proses garapan. Misal vokal yang kurang jelas, gestikulasi tubuh yang kurang pas, peran yang kurang dihayati, hafalan naskah yang dibuat sendiri, hingga waktu yang pas dalam sebuah adegan. Menurut Iman Soleh, hal tersebut penting dilakukan karena dalam teater tubuh adalah media utama pertunjukan. Tahap kedua adalah evaluasi dampak dari proses garapan hingga selesainya pertunjukan. Iman Soleh sering bertanya pada setiap akhir pertunjukan, mengenai dampak dari proses panjang yang telah dilakukan. Proses itu membuat setiap seniman yang terlibat memahami esensi dari sebuah proses pertunjukan. Misal, beberapa seniman sadar bahwa melalui proses tersebut mereka dapat mengasah kemampuan baru dalam bidang ilustrasi musik.

\section{Pengembangan diri di luar seni}

Pada dasarnya Komunitas CCL adalah sebuah komunitas teater. Namun, di dalam kegiatannya melakukan upaya pemberdayaan masyarakat di luar aktivitas berteater. Komuni- 
tas Celah-Celah Langit berupaya agar setiap anggota atau yang terlibat dalam kegiatannya tidak hanya melakukan aktivitas teater dalam rangka hiburan semata tetapi mereka harus berdaya secara sosial ekonomi dalam kehidupan sehari-harinya.

Di KCCL terdapat banyak orang yang bukan bagian dari keluarga Iman Soleh tinggal dan menetap di rumahnya. Kebanyakan dari mere$\mathrm{ka}$ adalah mahasiswa dari berbagai perguruan tinggi dan warga sekitar yang terlibat dalam garapan teater yang dipimpin oleh Iman Soleh. Menurut Iman Soleh, para mahasiswa sangat berpotensi dan ia ingin memberdayakan mereka dalam tiga hal yaitu: kesadaran terhadap pendidikan, kesadaran lingkungan dan kesadaran terhadap budaya.

\section{Penyadaran pentingnya pendidikan}

Iman Soleh adalah orang yang sangat mementingkan pendidikan. Ia menekankan hal itu tidak hanya diterapkan kepada anak-anak kandungnya, tetapi juga pada semua anggota Komunitas Celah-Celah Langit. Tidak semua anggota komunitas merupakan mahasiswa di perguruan tinggi, dan biasanya Iman Soleh selalu mendorong mereka yang bukan mahasiswa untuk melanjutkan studi ke perguruan tinggi. Ia bahkan membantu biaya pendidikan bagi beberapa anggota komunitas.

\section{Penyadaran peka lingkungan}

Seniman lekat dengan stereotype sebagai orang yang bebas dan kurang memperhatikan kerapihan (walaupun tidak semua seperti itu). Sementara Iman Soleh sangat peka terhadap kebersihan lingkungan. Hal itu juga diterapkannya pada setiap anggota Komunitas Celah-Celah Langit. Ia menjelaskan bahwa filosofi dari penerapan terhadap kepekaan lingkungan adalah perubahan yang dimulai masing-masing. Sebelum para anggota CCL mengubah sesuatu yang besar, mereka harus memulai dari lingkungan sekitarnya, termasuk dirinya sendiri. Sebab, menjadi seniman artinya memberikan inspirasi dengan lebih mendalam tentang lingkungannya. Ia juga mengingatkan bahwa menjadi seniman itu harus menyuarakan persoalan sekitarnya karena dia lahir untuk menjadi saksi bagi zamannya.

Iman Soleh mengatakan :

"Misalkan dalam Al Qur'an Ashura "apa yang kau ucapkan harus sesuai dengan apa yang kau lakukan". Misalkan kalau kita mau berbasis pada agama, apa yang kita ucapkan harus sesuai dengan apa yang kita lakukan, menjadi tindakan, tentunya yang paling mulia adalah tindakan mulia, bukan hanya gagasan yang mulia, bukan hanya bahasa yang mulia tetapi laku yang baik adalah laku yang mulia itu sendiri. Maka harus ada keterhubungan gagasan, ucapan dan tingkah laku. Misalkan kesenian yang memberikan tiga hal besar: etik, estetik dan edukasi, itu menjadi hal pokok, itu bukan hanya ada di Al Qur'an namun ada juga di wawacan, pantun, kawih, filsafat timur, filsafat kita tentang papat kalima pancer yang satu sama lain harus saling berhubungan, hubungannya dengan keyakinan".

Penerapan karakter peka lingkungan tidak hanya diterapkan oleh Iman Soleh pada anggota Komunitas Celah-Celah Langit. Penerapan karakter peka lingkungan juga diterapkan pada tamu yang menggunakan fasilitas Komunitas Celah-Celah Langit. Misal, Carlos Gomez seorang seniman dari Brazil yang ingin latihan di CCL, sebelum mulai latihan, ia diharuskan ikut menyapu lapang terlebih dahulu. Tujuannya agar para pemain terhindar dari paku, beling dan benda tajam lainnya yang ada di lapang. Manfaat lain dari kegiatan itu adalah agar tubuh mereka berkeringat dan siap mengikuti proses latihan. Manfaat berikutnya adalah agar mereka lebih disiplin mengenai kebersihan lingkungan.

Komunitas CCL menerapkan aturan kepada pengguna fasilitas panggung pementasan bahwa mereka tidak perlu membayar dengan uang, akan tetapi bayaran itu diganti dengan menanam pohon di sekitar area CCL. Hal itu menyimbolkan bahwa komunitas CCL sangat 
peduli terhadap kondisi lingkungan sekitar.

\section{Membangun kesadaran terhadap budaya}

Central-Culture of Ledeng adalah nama CCL sebelumnya. Nama lama tersebut pada dasarnya mencerminkan visi untuk melestarikan dan menjaga kebudayaan di Ledeng, tempat komunitas seni itu berada. Mustari, salah seorang warga Ledeng, menuturkan bahwa sejak dulu Ledeng dikenal dengan budaya tradisinya yang kental. Hal itu mewujud dalam norma etika budaya Sunda seperti sopan santun, dan hidup secara kolektif atau biasa di sebut Guyub dalam istilah Sunda. Kesenian tradisi pun berkembang pesat seperti "Bring-brung" yang merupakan kesenian terbangan buhun. Terbangan buhun merupakan bentuk kesenian sejenis rebana yang dimainkan dengan cara dipukul sambil melantunkan ayat-ayat suci yang berisi nasihat bagi kebaikan hidup masyarakat Ledeng. Bring-brung biasa dimainkan pada saat Muludan atau memperingati malam Maulid Nabi. Selain Bring-brung ada pula keseian wayang dengan dalang Pak Asep Sugandi atau Kang Iyep, Silat, Calung, Tonil dan Dangdut Ceu Yati. Namun, kesenian-kesenian itu memudar semenjak lokasi berkesenian dibangun menjadi terminal Ledeng, dan juga karena banyak warga asli yang memilih pindah rumah dan alih fungsi sawah menjadi indekos atau hotel. Berdirinya terminal Ledeng disinyalir turut memicu masuknya pengaruh dari luar sehingga mempengaruhi perubahan sosial budaya masyarakat Ledeng; dan pada akhirnya memudarkan aktivitas berkesenian para warganya.

\section{Hadirnya Komunitas Celah-Celah Langit} salah satunya untuk mengembalikan budaya yang terkikis tersebut. Para seniman tradisi difasilitasi ruang untuk kembali berkesenian. Tidak jarang dalam setiap produksi teater, KCCL menggabungkan seni tradisi asli yang ada di Ledeng dengan konsep teater CCL. Iman Soleh selalu menekankan pada anggota Komunitas Celah-Celah Langit untuk turut serta berperan menjaga tradisi budaya, khususnya budaya Sunda yang ada di Ledeng. Ia selaku pimpinan komunitas selalu mengedepankan musyawarah dalam setiap keputusan atau ketika ada suatu masalah yang harus di selesaikan. Hal itu guna memacu kembali semangat kolektivitas dan semangat guyub yang merupakan tradisi Sunda yang baik. Ia juga selalu menegaskan pada para anggotanya bahwa teater Celah-Celah Langit merupakan teater rakyat yang hampir semuanya bersumber dari tradisi budaya. Para anggota pun selalu ditekankan untuk bangga terhadap akar budayanya dan mengimplementasikan hal tersebut dalam kebutuhan teater maupun kebutuhan sehari-hari.

\section{Pemberdayaan masyarakat di Komunitas CCL: Analisis Antropologis}

Pada dasarnya CCL itu bukanlah lembaga pemberdayaan, karena aktivitas yang di lakukan adalah berkesenian, tidak seperti lembaga swadaya masyarakat yang pada umumnya bertujuan untuk memberdayakan masyarakat. Namun, dari kegiatan yang dilakukan CCL mengandung unsur pemberdayaan masyarakat, yaitu upaya penyadaran dan peningkatan daya-daya pada diri seseorang atau kelompok untuk memahami dan mengontrol dimensi-dimensi kekuatan yang dimiliki (fisik, psikis, sosial, dan budaya) untuk peningkatan kedudukan mereka di dalam masyarakat. Hal ini sejalan dengan konsep pemberdayaan yang dikemukakan oleh Kindervatter (1979:150),

Komunitas Celah-Celah Langit menganut aliran "seni untuk masyarakat", sehingga segala aktivitasnya didasarkan pada kepentingan masyarakat khususnya terkait dengan upaya pemberdayaan. Pemberdayaan melalui aktivitas seni yang dilakukan oleh Komunitas Celah-Celah Langit tidak berorientasi pada output ekonomi. Output yang diharapkan dari upaya pemberdayaan oleh Komunitas Celah-Celah Langit adalah bertambahnya daya kreativitas, kapasitas pendidikan, kemandirian dan kepekaan sosial terhadap fenomena yang sedang terjadi.

Di dalam setiap tahapan dalam proses kreatif 
teater Celah-Celah Langit, terdapat proses pemberdayaan masyarakat yang disebutkan oleh Wilson (1996): 1) Awakening atau penyadaran dan 2) Understanding atau pemahaman; 3) Harnessing atau pemanfaatan; dan 4) Using atau penggunaan.

Pada tahap awakening, masyarakat disadarkan akan kemampuan, sikap dan keterampilan yang dimiliki serta rencana dan harapan akan kondisi mereka yang lebih baik dan efektif. Proses pengumpulan pemain dan penentuan ide atau gagasan dalam proses kreatif teater CCL merupakan tahap awakening atau penyadaran. Sebab, di tahap ini masyarakat disadarkan akan kesetaraan dan potensi yang mereka miliki. Anggota CCL berasal dari beragam latar sosial, mulai dari mahasiswa jurusan teater, seniman teater, atau orang yang belum pernah mengenal seni seperti kuli bangunan, pengamen jalanan, ibu-ibu rumah tangga dan lain-lain. Di CCL, mereka saling melengkapi satu sama lain baik dalam konteks keilmuan maupun diluar konteks keilmuan. Tidak semua dari mereka berlatar belakang sebagai pemain teater, tetapi mereka disadarkan dalam sebuah kesetaraan bahwa setiap manusia pun memiliki kemampuan masing-masing. Proses penyadaran ini memacu kesadaran mereka terhadap fenomena sekitar yang membuat mereka sadar dan sensitif terhadap fenomena lingkungan, pendidikan dan budaya. Pada tahap kedua yaitu penentuan ide atau gagasan, setelah para pemain berkumpul, proses penyadaran terjadi lagi. Para pemain dikumpulkan dalam satu forum untuk menentukan ide atau gagasan mengenai apa yang akan di garap. Proses ini bertujuan agar para pemain berkontribusi langsung dalam melahirkan ide pementasan, dan tidak semata tergantung pada sutradara.

Tahap understanding atau pemahaman adalah tahap saat masyarakat diberi pemahaman dan persepsi baru mengenai diri mereka sendiri, aspirasi mereka dan keadaan umum lainnya. Tahap pematangan ide dan pembuatan naskah, melibatkan proses understanding. Para anggota memahami lebih dalam nilai-nilai edukatif dalam sebuah naskah seni.Pada tahap pematangan ide, para pemain berupaya memahami maksud dan tujuan karya yang akan dipentaskan tersebut. Selain mereka berteater, mereka juga harus paham mengenai teks yang mereka pentaskan, gerakan yang mereka lakukan dan dampak dari teater tersebut bagi pemain dan penontonnya. Pada tahap pembuatan naskah juga terjadi proses pemahaman. Pada tahap ini pemain paham dan sadar mengenai tema teater tersebut, dan mengetahui apa yang akan mereka tulis. Setelah itu mereka dilatih keterampilan menulis naskah agar berdampak kepada kepekaan mereka, mempunyai kemampuan menulis naskah dan memahami mengenai naskah yang akan mereka pentaskan.

Tahap harnessing atau pemanfaatan adalah tahap setelah masyarakat sadar dan mengerti mengenai pemberdayaan, saatnya mereka memutuskan untuk memanfaatkannya bagi kepentingan komunitasnya. Setelah pemain memahami naskah yang akan dipentaskan, mereka memulai latihan eksplorasi, desain artistik, menentukan tempat pertunjukan dan melakukan pertunjukan. Seluruh tahap ini adalah tahap harnessing. Pada tahap ini pemain teater menumbuhkan daya kreativitas mereka mengenai berbagai macam bentuk baru dalam hal teater, dari mulai olah tubuh, bahwa tubuh sebagai media utama teater, tubuh sebagai simbol, olah vokal, olah sukma (olah rasa) dan artistik yang mengimajinasikan gambaran pertunjukan agar saat pertunjukan dimulai, suasana dari pertunjukan benar-benar terbayang oleh para penonton. Tahap using adalah upaya pemain menggunakan keterampilan dan kemampuan pemberdayaan sebagai bagian dari kehidupan sehari-hari. Pada tahap ini, para pemain teater di CCL biasanya telah mampu memilih dan menggunakan aneka tema pertunjukkan sesuai dengan kepentingan yang ingin dicapai.

\section{Simpulan}

Komunitas Celah-Celah Langit melakukan 
proses pemberdayaan melalui pengembangan seni dengan tiga cara, pertama, melalui penyediaan fasilitas fisik, penyediaan pelatihan keterampilan seni dan penyediaan fasilitas pengembangan diri di luar seni. Penyediaan fasilitas fisik seperti ruang pertunjukan, perpustakaan dan ruang diskusi bertujuan untuk memfasilitasi masyarakat untuk berkesenian dan juga sebagai sarana edukasi dan penyadaran. Pada pelaksanaannya penyediaan fasilitas fisik telah banyak dimanfaatkan oleh komunitas dan masyarakat pada umumnya.

Penyediaan fasilitas keterampilan seni seperti pelatihan seni teater memberikan dampak pada terciptanya hubungan fungsional antara aktivitas seni teater dan upaya pemberdayaan masyarakat, dengan cara melibatkan masyarakat dalam kegiatan teater yang khas. Dengan kata lain, aktivitas teater yang dilakukan Komunitas Celah-Celah Langit merupakan suatu bentuk teater pemberdayaan.

Pengembangan diri di luar seni memungkinkan seniman dan warga masyarakat yang terlibat di CCL memiliki kesadaran budaya, kesadaran pendidikan dan kesadaran lingkungan. Semua kegiatan ini pada akhirnya mendorong terbangunnya masyarakat yang berdaya, yaitu masyarakat yang berpengetahuan, berkesadaran dan hidup berdaya.

\section{Daftar Pustaka}

Buzzard, J. (2003). On Auto-Ethnographic Authority. The Yale Journal of Criticism, 16(1), 61-91.

Chambers, R. (1995). Poverty and Livelihoods: Whose Reality Counts? In U. Kirdar, \& L. Silk, People: From Impoverishment to Empowerment. New York: New York University Press.

Djojopoespito, S. (2006). Memperkenalkan Center Cultures Ledeng dalam Upaya Meningkatkan Citra Pariwisata di Kota Bandung. Skripsi. Bandung: Sekolah Tinggi Bahasa Asing Yapari-Aba Bandung.

Green, G. P., \& Haines, A. (2002). Asset Building and Community Development. California:
Sage Publication Inc.

Iriantara, Y. (Manajemen Strategi Public Relations). 2004. Bandung: Ghalia Indonesia.

Jackson, M. D. (2008). Between Biography and Ethnography. Harvard Theological Review, 100(3-4), 377-397.

Kartasasmita, G. (1996). Pemberdayaan Masyarakat: Konsep Pembangunan yang Berakar pada Masyarakat. Makalah.

Kindervatter, S. (1979). Nonformal Education as An Empowering Process. Massachusetts: Center for International Education University of Masachusetts.

Koentjaraningrat. (2015). Pengantar Antropologi. Jakarta: Rineka Cipta.

Payne, M. (1991). Modern Social Work Theory. London: Macmillan Press Ltd.

Sayoga. (1985). Kumpulan Istilah Indonesia Baru. Bandung: Alumni.

Setiawan. (2009). Kemunculan dan Perkembangan Komunitas Celah-Celah Langit. Skripsi. Bandung: STSI.

Soetomo. (2006). Strategi-strategi Pembangunan Masyarakat. Yogyakarta: Pustaka Pelajar.

Suharto, E. (2009). Membangun Masyarakat Memberdayakan Masyarakat. Bandung: PT Refika Aditama.

Sumaryadi, N. (2005). Perencanaan Pembangunan Daerah Otonom dan Pemberdayaan Masyarakat. Jakarta: Citra Utama.

Wijaya, P. (2007). Teater. Jakarta: Lembaga Pendidikan Seni Nusantara.

Zubaedi. (2013). Pengembangan Masyarakat. Jakarta: Kencana. 